www.jmscr.igmpublication.org Impact Factor 5.84 Index Copernicus Value: 71.58 ISSN (e)-2347-176x ISSN (p) 2455-0450

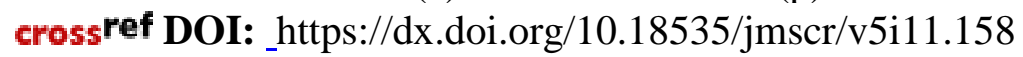

\title{
Microbiological Profile of Neonatal Septicemia in a Rural Teaching Hospital of North India
}

\author{
Authors \\ Dr Rajesh Rathi ${ }^{1}$, Dr Baljeet Maini ${ }^{2}$, Dr Anchal Saini ${ }^{3}$ \\ ${ }^{1}$ PG Resident, Department of Pediatrics, MMIMSR, Mullana \\ ${ }^{2}$ Professor, Department of Pediatrics, MMIMSR, Mullana \\ ${ }^{3}$ Senior Resident, Department of Pediatrics, MMIMSR, Mullana \\ Corresponding Author \\ Dr Baljeet Maini \\ Professor, Department of Pediatrics, MMIMSR, Mullana \\ Email: mainibaljeet@gmail.com
}

\begin{abstract}
Objectives: To study the microbiological profile of neonatal septicemia and to determine the antimicrobial resistance pattern of isolated bacteria.

Study Design: retrospective analysis of blood culture reports of neonatal septicemia cases.

Setting: tertiary level neonatal intensive care unit

Patients and Methods: case records of neonatal septicemia cases were retrieved and their culture results were analysed in terms of causative organisms and their antimicrobial sensitivity patterns. Extended spectrum beta lactamamse (ESBL) resistance and methicillin resistant Staphylococcus Aureus (MRSA) patterns were studied.

Results: out of 162 samples, bacterial growth was detected in 53 samples. Gram negative growth was around 66 percent and rest were gram positive. Gram negative organisms accounted for more than 75 percent in both early and late onset sepsis. Out of 12 blood cultures showing Staph Aureus, 7 (58\%) were MRSA. Vancomycin was the drug to which all MRSA growths were sensitive. Out of 34 gram negative infections, 13 were ESBL in whom Klebsiella sp. was the most common followed by E. coli. All ESBL organisms were sensitive to Imipenem.

Conclusion: gram negative organisms predominated in the neonatal septicemia. MRSA and ESBL strains hold a large share of the bacterial growths.
\end{abstract}

\section{Introduction}

Septicemia in neonates is the widespread bacterial infection recognized in first four weeks of life by positive blood culture ${ }^{(1)}$. In developing countries, factors that predispose newborns to risk of developing neonatal sepsis compared with developed countries include intrinsic factors and extrinsic factors in the antenatal, intra-partum and the neonatal period. According to World Health Organization (WHO) every year there are about 5 million neonatal deaths due to neonatal infections $^{(2)}$. Onset of septicemia can be early $(<72 \mathrm{hrs})$ and late ( $\geq 72 \mathrm{hrs}-28$ days). Early onset sepsis (EOS) is attained during fetal life, caused 
by organisms prevalent in the maternal genital tract, infecting the neonate transplacentally or during passage through a colonized birth canal at the time of delivery or at the nursery ${ }^{(3)}$. The late onset sepsis (LOS) is acquired from environment (hospital) usually intensive care units (NICU) or the community. The infant's skin, respiratory tract, conjunctiva, gastrointestinal tract and umbilicus may become colonized from the environment and such colonization may lead to possibility of late onset septicemia from invasive microorganisms. During the past decade, extended spectrum beta lactamase (ESBL) and methicillin resistant staph aureus (MRSA) strains have repeatedly been implicated in neonatal intensive care units at tertiary care hospitals. Microorganisms develop resistance continuously by modifying or replacing the target that is penicillin binding protein (PBP) or acquiring betalactamases and other mechanisms.

Emergence of various $\beta$-lactamases producing multi-drug resistant strains is one of the prominent causes of septicemia, which obscures the clinical as well as therapeutic outcomes. ${ }^{(4)}$ Sepsis with ESBL producing bacteria is increasingly acknowledged in Asian countries in recent years ${ }^{(5)}$. Also, Metallo-beta lactamases and Amp C beta lactamase producing GNB have emerged in neonatal septicemic case. Failure to detect various lactamases enzymes and their combination in the same organism has contributed to therapeutic failures. ${ }^{(6)}$

The organisms causing neonatal septicemia keeps changing over time and varies from place to place, due to change in lifestyle and also altering pattern of antibiotics use. Every hospital should have a policy to keep on evaluating the microbiological pattern of infection cases so that upgradation of treatment protocols can be done. This study was conducted as such an exercise to determine the microbiological profile and antibiotic susceptibility pattern in bacteria from suspected neonatal septicemia cases admitted in NICU of MMIMSR, Mullana.
Objectives

- To study the microbiological profile of neonatal septicemia and to determine the anti-microbial sensitivity pattern of isolated bacteria.

- To find out the rate of ESBL, and rate of MRSA in neonatal septicemic cases.

\section{Material and Methods}

Study Design - A retrospective study of bacterial isolates in neonatal septicemia cases

Study Population: Case records of neonatal septicemia (admitted between January 1, 2015 to December $\left.31^{\text {st }} 2015\right)$ were retrospectively analysed. Study was conducted on blood culture reports of all neonates in neonatal intensive care unit (NICU) with suspected septicemia during a study period of 1 year.

\section{Study Size and Sampling}

Case records were selected in whom, blood culture showed the growth of microorganism.

\section{Exclusion Criteria}

Neonates already on antibiotics prior to admission antenatal diagnosis of intra-uterine infection, fungal growth/ mixed growth/ growth labeled as contaminant by physician

Ethics Consideration- The ethics clearance was taken from ethical committee.

Data Collection: details of clinical records were recorded in the Microsoft excel datasheet and analysed

\section{Results}

out of total 162 cases of neonatal septicemia the culture positive cases were 55 hence the culture isolation rate was $(33.95 \%)$. the predominance was of bacterial isolates (95.45\%) as compared to fungal isolates $(4.55 \%)$. The 5 fungal isolates were found to be candida sp. distribution of bacterial isolates, showing Gram negative $(64.15 \%)$ was predominant than gram positive $(35.85 \%)$. Table I - Exhibits demographic characteristics of neonatal septicemic cases. Male cases 35(66.03\%) were more than female cases $18(33.96 \%)$. Pre term cases were $13(24.52 \%)$, term cases were 
40(75.47\%). Birth weight of neonates less than $1500 \mathrm{~g}$ were $12(22.64 \%), 1500-2500 \mathrm{~g}$ were $35(66.03 \%)$, more than $2500 \mathrm{~g}$ were $6(11.32 \%)$ Table II- illustrates that among culture positive neonates, 42 (79.24\%) were having EOS and 11(20.75\%) were having LOS .In EOS hospital deliveries were more $(87.5 \%)$ in contrast to LOS where outborn babies were more. Table IIIIllustrates In gram negative acinetobacter spp was $37.68 \%$ followed by klebsiella (28.98\%), Ecoli (14.49\%), pseudomonas $\mathrm{sp}(8.69 \%)$, Citrobacter spp $(5.8 \%)$ and Enterobacter $\mathrm{sp}(2.89 \%)$. However, in Gram positive (35.85\%) staph aureus $(60.53 \%)$ was predominant followed by staph epidermidis (21.05\%) and Enterococcus $(18.42 \%)$. Table IV - Depicts distribution of isolates in early onset septicemia. In EOS, MRSA was $66.66 \%$, among ESBL producing isolates Klebsiellaspp (23.80\%) and S. aureus (21.42\%) were predominent followed by Citrobacterspp (50\%), Enterobacterspp (100\%) and Acinetobacterspp (12.5\%). Table V- Showing distribution of isolates in Late onset septicemia. In LOS, Acinetobacterspp (36.36\%), S.aureus (27.27\%), E.coli (18.18\%), pseudomonas spp (9.09\%), Klebsiellaspp (9.09\%) were isolated.-. MRSA ( 7 out of total 12 staph aureus patients,
$58.33 \%$ ) were more than MSSA (41.66\%). maximum susceptibility pattern of MRSA was to Vancomycin (100\%) followed by Gentamicin (71.4\%), linezolid (71.43\%), Azithromycin $(57.1 \%)$, Tetracycline $(57.14 \%)$, co-trimoxazole (42.86\%), Ciprofloxacin (28.57\%), MRSA showed $100 \%$ resistance to Penicillin. Table VI Shows distribution of ESBL, among gram negative isolates of neonatal septicemia. ESBL (38.23\%) ESBL was exhibited by Klebsiellaspp $53.84 \%$, Ecolispp 23\%, Citrobacterspp 7.69\%, Enterobacterspp $7.69 \%$ and Acinetobacterspp 7.69\%. In case of ESBL all isolates showed $100 \%$ senstivity to imipenem, followed by amikacin (76.92\%), piperacillin/tazobactam $\quad(46.15 \%)$, meropenem (46.15\%), ampicillin (7.69\%), chloramphenicol $(23.07 \%)$, cefepime $(30.76 \%)$, ciprofloxacin $(30.76 \%)$, gentamicin $(23.07 \%)$, tobramycin (23.07\%), kanamycin (7.69\%), tetracycline $(7.69 \%)$.

Table I- Patient's characteristics of neonatal septicemia $(n=53)$

\begin{tabular}{|l|c|c|}
\hline Gender & Male & $35(66.03 \%)$ \\
& Female & $18(33.96 \%)$ \\
\hline Gestation & Preterm & $13(24.52 \%)$ \\
& Term & $40(75.47 \%)$ \\
\hline Birth weight(g) & Very low<1500 & $12(22.64 \%)$ \\
& Low1500-2500 & $35(66.03 \%)$ \\
& $>2500$ & $6(11.32 \%)$ \\
\hline
\end{tabular}

Table II: Distribution of cases according to age of onset-

\begin{tabular}{|c|c|c|c|c|}
\hline Culture positive cases & \multirow{2}{*}{\multicolumn{2}{|c|}{$\frac{\text { EOS }}{42(79.24 \%)}$}} & \multicolumn{2}{|c|}{ LOS } \\
\hline \multirow{3}{*}{53} & & & & 75) \\
\hline & $\begin{array}{l}\text { Hospital } \\
\text { Delivery }\end{array}$ & Outborn Babies & $\begin{array}{l}\text { Hospital } \\
\text { Delivery }\end{array}$ & Outborn Babies \\
\hline & $36(85.71 \%)$ & $6(14.28 \%)$ & $2(18.18 \%)$ & $9(81.81 \%)$ \\
\hline
\end{tabular}

Table III- Distribution of bacterial isolates

\begin{tabular}{|l|c|c|c|c|}
\hline \begin{tabular}{l} 
Total $\begin{array}{c}\text { number of } \\
\text { bacterial isolates }\end{array}$ \\
\hline 53
\end{tabular} & Organism & $\mathrm{N}=19$ & \multicolumn{2}{c|}{ Gram negative isolates } \\
& $(35.85 \%)$ & organism & $\mathrm{N}=34(64.15 \%)$ \\
\cline { 2 - 5 } & Staphylococcus aureus & $12(60.53 \%)$ & Acenitobacterspp & $13(37.68 \%)$ \\
\cline { 2 - 5 } & Staphylococcus epidermidis & $4(21.05 \%)$ & Klebsiellaspp & $10(28.98 \%)$ \\
\cline { 2 - 5 } & Enterococcus & $3(18.42 \%)$ & Escherichia coli & $5(14.49 \%)$ \\
& & & Pseudomonas spp & $3(8.69 \%)$ \\
& & & Citrobacterspp & $2(5.8 \%)$ \\
& & & Enterobacter & $1(2.89 \%)$ \\
& & & Alcaligenesfaecalis & 0 \\
\hline
\end{tabular}


Table IV - Distribution of isolates in early onset septicemia (EOS)

\begin{tabular}{|l|c|c|c|}
\hline ORGANISM & $\begin{array}{c}\text { Number of } \\
\text { isolates } \\
(\mathrm{N}=42)\end{array}$ & MRSA & ESBL \\
\hline Klebsiellaspp & $10(23.80 \%)$ & & $8(80 \%)$ \\
\hline S.aureus & $9(21.42 \%)$ & $6(66.66 \%)$ & \\
\hline Acinetobacterspp & $8(19.04 \%)$ & & $1(12.5 \%)$ \\
\hline CoNS & $4(9.52 \%)$ & & 0 \\
\hline Ecolispp & $3(7.14 \%)$ & & $2(66.66 \%)$ \\
\hline Enterococcus spp & $3(7.14 \%)$ & & 0 \\
\hline Pseudomonas spp & $2(4.76 \%)$ & & 0 \\
\hline Citrobacterspp & $2(4.76 \%)$ & & $1(50 \%)$ \\
\hline Enterobacterspp & $1(2.38 \%)$ & & $1(100 \%)$ \\
\hline $\begin{array}{l}\text { Alcaligenes } \\
\text { faecalis }\end{array}$ & & & 0 \\
\hline
\end{tabular}

Table $\mathbf{V}$ - Distribution of isolates in Late onset septicemia (LOS)

\begin{tabular}{|l|c|c|}
\hline ORGANISM & Number of isolates & ESBL \\
\hline Acinetobacterspp & $4(36.36 \%)$ & 0 \\
\hline s.aureus & $\begin{array}{c}3(27.27 \%) \\
\text { MRSA 1(33.33\% OF } \\
\text { staph infections) }\end{array}$ & 0 \\
\hline Ecolispp & $2(18.18 \%)$ & $1(50 \%)$ \\
\hline Pseudomonas spp & $1(9.09 \%)$ & 0 \\
\hline Klebsiellaspp & $1(9.09 \%)$ & 0 \\
\hline Total & 11 & 0 \\
\hline
\end{tabular}

Table VI -Distribution of ESBL isolates in Gram negative bacilli:

\begin{tabular}{|l|c|}
\hline Name of organism & ESBL \\
\hline Acinetobacterspp(13) & $1(7.69 \%)$ \\
\hline Klebsiellaspp(10) & $7(53.84 \%)$ \\
\hline E.coli spp (5) & $3(23 \%)$ \\
\hline Pseudomonas spp(3) & 0 \\
\hline Citrobacterspp (2) & $1(7.69 \%)$ \\
\hline Enterobacterspp (1) & $1(7.69 \%)$ \\
\hline TOTAL $=34$ & 13 \\
\hline
\end{tabular}

\section{Discussion}

Neonatal sepsis is a clinical syndrome characterized by systemic signs of infection and accompanied by bacteremia in the first month of life. An early diagnosis of neonatal septicemia is vital for proper treatment. A planned and appropriate use of antibiotics, efficient hospital policies, thorough and precise detection of resistant species, is required to check the increasing incidence of antimicrobial resistant organisms. Appropriate antibiotic policy can be made once microbial flora patterns are known along with their sensitivity analysis. The present study revealed that amongst a total of 162 clinically suspected cases of neonatal septicemia blood cultures from 55(33.85\%) were positive which was in accordance with Roy II et al $(47.5 \%)$ from $^{(7)}$ and Kayange.N et al $(38.9 \%){ }^{(8)}$. This is In contrast to more developed countries with better healthcare infrastructures. ${ }_{-}^{\left({ }^{9}\right)}$ The range of organisms causing neonatal sepsis varies in time and place. The data of the present study showed bacterial isolates (96\%) were more than fungal isolates(4\%) similar to various other Indian studies $^{(10)(11)(12)}$. This study there was the predominance of gram negative $(64 \%)$ over gram positive isolates (35\%). In current study GN isolates $(64.49 \%)$ were more than GP isolates $(35.51 \%)$ which is consistent with (13)(14) - Our results are also consistent with the recent analysis at which showed similar flora pattern in similar time frame.

In gram positive isolates majority was staph. aureus $60.53 \%$ followed by staph. epidermidis $21.05 \%$, Enterococcus $18.42 \%$. in gram negative bacteria, leading organism was Acenitobactersp (37.68\%) followed by Klebsiella pneumonia (28.98\%), Escherichia coli (14.49\%), Citrobactersp (10.14\%), Pseudomonas sp (8.69\%) and Enterobacter (2.89\%). S.aureus was most usual Gram-positive organism and among all isolates the second most common organism. A substantial percentage $(21.05 \%)$ was Coagulase negative staph aureus (CONS). In case of Gram negative bacilli the predominant organism was Acinetobacter species (37.68\%) followed by Klebsiella 30744neumonia $(28.98 \%)$ and $E$ coli $(14.49 \%)$ in present study which is in accordance to Marwah.P et $\mathrm{al}^{(15)}$ Acinetobacter (14.9\%) and Klebsiella pneumonia (14.9\%), Mishra. $\mathrm{A}^{(16)}$ Acinetobactersp (31.5\%), E.coli (26.3\%), Klebsiella pneumonia (10.7\%). Nonfermenter, Acinetobacter appeared as significant nosocomial pathogen in neonates. Klebsiella was the predominant organism in a similar study ${ }^{(17)}$ (Klebsiellasp 22.53\%, Pseudomonas sp 21.12\%, Acinetobacter sp $15.49 \%$ ) 
The upward moving graph of prevalence of MRSA in NICUs reflected by the recent data and the consequent evolution of its various strain within the hospital and community settings suggest its alarming trendas a pathogen. In present study, 7(58\%) were MRSA which were more than MSSA similar to Chelliah. A et al ${ }^{(18)}$ (MRSA $56 \%)$ in contrast Kaistha.N et al ${ }^{(19)}(11.11 \%)$. The higher rate of MRSA could, to a great extent be attributed to the fact that these organisms are now both hospital acquired and community flora. In present study all MRSA were $100 \%$ sensitive to Vancomycin. Present study demonstrates $100 \%$ sensitivity to vancomycin followed by Gentamicin (71\%), linezolid (71.43\%), azithromycin (57\%), tetracycline (57.14\%), co-trimoxazole (42.86\%), ciprofloxacin (28.57\%), Erythromycin (28\%) and clindamycin , levofloxacin (14.29\%) and analogous with Pandey.S et al ${ }^{(20)}$ with Vancomycin (100\%), Gentamicin $(79.32 \%)$ but in contrast to Saravanan. M et $\mathrm{al}^{(21)}$ with oxacillin (100\%), Vancomycin $(75 \%)$.The antibiotic susceptibility pattern varies in space and time and within localized communities as well.

ESBLs are now a problem in hospitalized patients throughout the world. The study revealed ESBL production $(38.2 \%)$ majority were klebsiella (53\%) and Ecoli strains (23\%) this is closer to study by Chellaih. A et al (18) (ESBL 67.3\%, Klebsiella $70.9 \%$, Ecoli 57.14\%), Kamble.R and Ovhal.R (17) (Klebsiella 62.5\%, Ecoli 20\%), Bhattacharjee. A et al ${ }^{(10)}$ (Klebsiella $62.7 \%$, Ecoli $46.5 \%)$. The extensive use of broad spectrum $\beta$ lactam antibiotics has led to marked increase in the incidence of Amp C in Gram negative organisms particularly family Enterobacteriaceae. In current study, 1(50\%) Klebsiella isolates in which both ESBL and Amp C are co-expressed in the same isolate and $1(50 \%)$ Escherichia coli isolates were $\mathrm{AmpC} \beta$-lactamase producers similar to Subitha.B et al ${ }^{(22)}$ with Klebsiellasp ( $25 \%$ ) and Ecoli (11\%).All ESBL isolates were sensitive to imipenem (100\%) followed by amikacin(77\%), piperacillin/tazobactam (46\%), meropenem (46), ampicillin (7.7\%), chloramphenicol(23\%), cefepime (26.92\%), ciprofloxacin (23.08\%), gentamicin (19.23\%), tobramycin (11.54\%), kanamycin $(7.69 \%)$, tetracycline $(7.6 \%)$ (Table VII) similar to Kulkarni.R et al imipenem (100\%), amikacin $(70.4 \%)$, Chelliah. A et $\mathrm{al}^{(18)}$ imipenem $(100 \%)$ in contrast to Singh.et al ${ }^{(23)}$ Imipenem (65.62\%), Piperacillin/tazobactam $(56.25 \%)$ and Amikacin (34.36\%). The $100 \%$ sensitivityto imipenem signifies the absence of selective pressure thus can be dispensed only after antibiotic susceptibility testing

National Neonatal Perinatal database (NNPD) 2003 categorizes sepsis as EOS (presenting within 72 hours of birth) and LOS (presenting 72 hours after birth).In the present study, out of 53 culture positive (bacterial) cases, EOS (79\%) was more frequent than $\operatorname{LOS}(21 \%)$ which is in agreement with Samaga.M.P et al ${ }^{(14)}(53.6 \%$, 46.4\%), Mustafa.M et $\mathrm{al}^{(13)}(58 \%, 42 \%)$, Premalatha. D.E et al $(78.5 \%, 21.5 \%){ }^{(24)}$ On the contrary, Kayange . N et al ${ }^{(8)}(\mathrm{EOS}-47 \%$, LOS$51.4 \%)$, Thakur.S et al (LOS 51\%,EOS $49 \%)^{(25)}$ LOS was predominant

In present study, Klebsiella $s p(24 \%)$ and s.aureus $(21 \%)$ were predominently isolated from EOS which is similar to Mane.A.K et al ${ }^{(26)}$ klebsiella $(20.83 \%)$, S.aureus $(20.83 \%)$ but in contrast to Gandhi.S et al ${ }^{(27)}$ with Ecoli $(26.08 \%)$, s.aureus $(23.91 \%)$ and Shehab El-din.E.M.R et al ${ }^{(28)}$ shows predominance of CoNS, Acinetobacter. Majority cases of MRSA, ESBL, MBL were reported in EOS as compared to LOS. Further in EOS, MRSA was shown by $(66 \%)$. The present study depicted predominance of Staph aureus in EOSas compared to LOS. EOS is considered to pass from mother to child at time of labour and during delivery. S.aureus often colonises the human skin, mucous membranes. Out of 3 E.colisp 2 produced ESBL $(66 \%)$ followed by Klebsiella $s p(80 \%)$, Citrobacter sp (50\%), Enterobacter sp (50\%), Acinetobacter sp (5.56\%). Predomience of E.coli could be explained by the fact that E.coli is normal vaginal flora but irrational use of antibiotics can cause change in E.coli producing ESBL which gets transmitted to neonates during 
delivery. In present study, predominent organisms isolated in LOS was acinetobacter sp (36\%) followed by S.aureus (27\%). This is similar to Shrestha .N.J et $\mathrm{al}^{(29)}$ E.coli $(52.3 \%)$, s.aureus $(46.7 \%)$ as predominent organisms But in contrast with Gandhi.S et al (27) CoNS (19.44\%) and klebsiella pneumoniae (16.67\%). MRSA was shown by 2 out of 3 S.aureus isolates $(67 \%)$. Similarly, out of 2 E.coli sp 1(50\%) showed ESBL,

LWB and prematurity have been mentioned to be significant risk factors for neonatal sepsis In the current study, neonatal septicemic cases in males (67\%) were reported more than females (33\%) which is similar to Khinchi.Y.R et al ${ }^{(30)}$ with male $(65.1 \%)$, female $(34.9 \%)$ and Shehab El- din. E.M.R et $\mathrm{al}^{(28)}$ male $(61.2 \%)$, female $(38.8 \%)$. Perhaps the synthesis of $\gamma$-globulins was regulated by $\mathrm{X}$-linked immune regulatory genes and males with one $\mathrm{X}$ chromosome are more susceptible for neonatal septicemia than females. In present study, preterm neonates were $25 \%$ and term neonates were $75 \%$ this is in accordance with Shrestha.P et al ${ }^{(31)}$ with preterm cases $(24.27 \%)$, term $(72.81 \%)$. Also, in present study, neonates with birth weight $<1500 \mathrm{~g}$ were $21.82 \%, 1500$ $2500 \mathrm{~g}$ were $67.27 \%$ and $>2500 \mathrm{~g}$ were $10.91 \%$ which was in accordance to Shehab El-din et al (28) VLBW (6.9\%), LBW (62.8\%), >2500g $(30.3 \%)$.

\section{Conclusion}

In this study, out of 162 cases, the culture positive cases were 55 (34\%),

Predominance was of bacterial isolates (96\%) as compared to fungal isolates (4\%)

MRSA (58\%) was more than MSSA (42\%). MRSA showed $100 \%$ sensitivity to Vancomycin. Among GNB, ESBL production was seen in $38 \%$ isolates

Antibiotic susceptibility pattern of ESBL, showed $100 \%$ senstivity to imipenem by all isolates and lowest was to tetracycline (7\%).
To overcome the problem of community acquired drug resistance and MDR which is a domain of hospital, a combined effort between the microbiologists, and physicians is required. We endorse the periodic appraisal in antibiotic policy in the hospital according to available data of antibiotic sensitivity and microorganism profile from time to time. Proper antibiotic policy to restrict the indiscreminate use of antibiotics particularly cephalosporins and carbapenems should be taken to minimize the emergence of beta lactamase producing pathogens.

\section{References}

1. Chandel DS, Johnson JA, Chaudhry R, Sharma N, Shinkre N, Parida S, et al. extended-spectrum B-lactamase producing gram negative bacteria causing neonatal sepsis in india in rural and urban settings. $\mathrm{J}$ med microbial.2011;60(4);500-7.

2. Jyothi P, Basavaraj MC, Basavaraj P V. bacteriological of neonatal septicaemia and antibiotics susceptibility pattern of isolates. J Nat Sci Biol Med [internet]2013;4(2):306-9. Available from: http://www.pubmedcentral.nih.gov/articler ender.fegi ?artid=3783770\&to01=pmcentre $z \&$ rendertype $=$ abstract accessed on june 30,2017

3. Donald Waters, Issrah Jawad, Aziez Ahmad, Ivana Lksic, Harish Nair, Lina Zgaga, Evropi Theodoratou, Igor Rudan, Anita K.M. Zaidi, and HC. Aetiology of community acquired neonatal sepsis in low and middle income countries. J Globe Heal [internet].Available from: http://www.ncbi.nlm.nih.gov/pmc/articles/ PMC3484773/ accessed on june 30,2017

4. Ann L Anderson-BerryAnn L AndersonBerry, MD,PhD Associate Professor of Pediatrics, Section of Newborn Medicine, University of Nebraska Medical Centre, Creighton University School of Medicine; Medical Director NICU NMC, Ann L Anderson-Berry $\mathrm{MD}, \mathrm{PhD}$ is a member of 
following medical societies: American Academy of Pediatrics, Nebraska Medical Associatio $\mathrm{S}$ for PR, Disclose.DN to coauthor(s), Linda L Bellig, MA RN NNP, (Retired) Track Coordinator, Instructor, Neonatal nurse Practitioner Program MU of SSC of N, Disclose. DN to, et al. Neonatal sepsis.2015; available from: http://emedicine.medscape.com/article/978 352-overview\#a4 accessed on june 30,2017

5. Peirovifar A, Ahangar M, Gharehbaghi MM. Prevalence of multidrug Resistant Extended-spectrum Beta-lactamse producing Gram-Negative Bacteria in Neonatal Sepsis Introduction: Int $\mathbf{J}$ Women`s Heal Reprod Sci.2014;2(3)

6. Nachhatarjitsingh, pavneetkaur, aruna Aggarwal. Neonatal septicaemia bt betalactamases producing multi-resistant organism-cause of concern.Int $\mathrm{J}$ basic Sci[internet].2016;7(1). Available from: http://www.ijbms.com/microbiology/neonatal-septicemia-by-betalactamse-producing-multiresistantorganism-cause-of-concern-nachhatarjitsingh-pavneet-kaur-aruna-aggarwal/ accessed on june 30,2017

7. Roy 11, Jain A, kumar M AS. Bacteriology of neonatal septisemia in a tertiary care hospital of northern india. Indian J Med Microbiol [Internet]. 2002;20(3):156-9. Available from: http://www.ncbi.nlm.nih.gov/pubmed/176 50757. accessed on june 30,2017

8. Kayange N, Kamugisha E, Mwizamholya DL, Jeremiah S, Mshana SE. Predictors of positive blood culture and deaths among neonates with suspected neonatal sepsis in tertiary hospital, Mwanza-Tanzania.2010.

9. Mohammad S, Aletayeb H, Khosravi AD, Dehdashtian M, Kompani F, Mortazavi SM, et al. Identification of bacterial agents and antimicrobial susceptibility of neonatal sepsis: A 54-month study in tertiary hospital. African J Microbiol Res. 2011;5(5):528-31

10. A Bhattacharjee, MR Sen, P Praksh, A Gaur SA. Increased prevalence of Extended Spectrum B Lactamase Producers in Neonatal Septicemic Cases At a Tertiary Referral Hospital. Indian J Med Microbiol [internet]2008;26(4):356-60.

11. Arora U, Devi P. Bacterial profile of blood stream infections and antibiotic resistance pattern of isolates. JK Sci.2007;9(4):18690

12. Dhara M, Disha P, Sachin P, Manisha J, Seema B, Vegad MM. Comparison of Various Methods For The Detection Of Extended Spectrum Beta Lactamase In Klebsiella Pneumoniae Isolated From Neonatal Intensive Care Unit. Natl J Med Res.2012;2(3):348-53.

13. Mustafa M, Ahmed SL. Original article Bacteriological profile and antibiotic susceptibility pattern in neonatal septicaemia in view of emerging drug resistance. J Med Allied Sci.2014;4(1):2-8.

14. Samaga MP, Sumangala B. Bacteriological profile of neonatal septicaemia in MIMS, Mandya, India. Int J Curr Microbiol Appl Sci.2016;5(3):495-501.

15. Marwah P, Chawla D, Chander J, Guglani $\mathrm{V}$, Marwah A. Bacteriological profile of neonatal sepsis in tertiary care hospital of north India. Indian Pediatr. 2015;52[2]: 158-9.

16. Gupt PK, Patra DP. Acinetobacter sepsis in new born. Indian Pediatr. 1998;35:2732.

17. Kamble R, Ovhal R. Original research article Bacteriological Profile of Neonatal Septisemia. Int J Curr Microbiol Appl Sci. 2015;4(2):172-82

18. Chelliah A, Ravinder T, Katragadda R, Leela KV, Narayana Bahu R. isolation of MRSA, ESBL and AmpC-B -Lactamses from neonatal sepsis at a tertiary care 
hospital. J Clin Diagnostic Res.2014;8 (6):24-7.

19. Kaistha N, Mehta M, Singla N, Garg R, Chander J. Letter to the Editor Neonatal septicaemia isolates and resistance patterns in a tertiary care hospital of North India. J Infect Dev ctries.2007;4(1):55-7.

20. Pandey S, Raza MS, Bhatta CP. Prevalence and Antibiotic Sensitivity Pattern of Methicillin-Resistant-Staphylococcus aureus in Kathmandu Medical College Teaching Hospital. J Inst Med.2012;34 (1):13-7.

21. Saravanan M, Nanda A, Tesfaye $T$. antibiotic Susceptibility Pattern of Methicillin Resistant Staphylococcus aureus from Septicaemia Suspected Children in Tertiary Hospital in Hosur, South India. Am J Microbiol Res [internet].2013;1(2):21-4.

22. Subitha B, Selvan BS. Plasmid mediated AmpC beta lactamase producing gram negative isolates in neonatal septicaemia. Int J Curr Microbiol Applsci [internet].2015;4(8):391-8 Available from: http:// www.ijcmas.com/vol-4-8/B.senthil selvan.pdf accessed on june 30,2017

23. Roy S, Gaind R, Chellani H, Mohanty S, Datta S, Singh AK, et al. Neonatal septoicemia caused by divers clones of Klebsiella pneumonia \& Escherichia coli harbouring blaCTX-M-15. Indian J Med Res.2013;137(4):791-9.

24. Premalatha DE, Koppad M, Halesh LH, Siddesh KC, Prakash N. The Bacterial Profile and Antibiogram of Neonatal Septicemia in a Tertiary Care Hospital. Int J Recent Trends Sci Technol.2014; 110(3):451-5.

25. Thakur S, Thakur K, Sood A, Chaudhary S. Bacteriological profile and antibiotic sensitivity pattern in neonatal septicaemia in a rural tertiary care hospital in North
India. Indian j Med Microbiol.2016; 9(4):67-71.

26. Mane AK, Nagdeo N V, Thombare VR. Study of neonatal septicaemia in a tertiary care hospital in rural Nagpur. J Recent AdvAppl Sci.2010;25:19-24.

27. Gandhi S, Ranjan K, Ranjan N, Sapre N, Masani $\mathrm{m}$. Incidence of neonatal sepsis in tertiary care hospital: An overview. Int J Med Sci Public Heal [internet]. 2013;2(3):522 Available from: http;//www.scopemed.org/?mno=34358. accessed on june 30,2017

28. Shehab El-Din EMR, El-Sokkary MMA, Bassiouny MR, Hassan R. epidemiology of Neonatal Sepsis and Implicated Pathogens: A Study from Egypt. Biomed Res Int [internet]. 2015;2015:1-11. Available from: ttp:/www.hindawi.com/journals/bmri/2015 /509484/ accessed on june 30,2017

29. Shrestha, N.J.Subedi, K.U.Rai GK. Bacteriological profile of neonatal sepsis: a hospital based study. J Nepal paediatr Soc 2011.2011;31(1):1-5.

30. Khinchi Y, Kumar A, Yadav S. Profile of Neonatal sepsis. J Coll Med Sci.2010;6(2):1-6.

31. Shrestha P, Das B, Bhatta N, Jha D, Setia A, et al. Clinical and Bacteriological profiles of blood culture Positive Sepsis in Newborns. Vol.27, Journal of Nepal Paediatric Society.2009.p.64-7. 